\title{
ANALISIS KELAYAKAN BUKU TEKS PINTAR BAHASA INDONESIA KELAS VII SMP/MTS SEMESTER I
}

\author{
Prameswari Dyah Gayatri B.A.I \\ Prodi Pendidikan Bahasa dan Sastra Indonesia \\ Universitas Negeri Yogyakarta \\ dyahgayatri644@gmail.com
}

\begin{abstract}
ABSTRAK
Tujuan penelitian analisis ini adalah untuk mendeskripsikan: (1) sistematika penyajian buku teks Pintar Bahasa Indonesia kelas VII semester I; (2) keruntutan penyajian buku teks Pintar Bahasa Indonesia kelas VII semester I; (3) kelayakan isi buku teks Pintar Bahasa Indonesia kelas VII semester I; (4) kelayakan penyajian bahasa dalam buku teks Pintar Bahasa Indonesia kelas VII semester I. Penelitian ini menggunakan metode analisis konten dengan sumber utama buku teks Pintar Bahasa Indonesia kelas VII SMP/MTs Semester I. Pemeriksaan keabsahan data menggunakan validitas semantik dan reliabilitas interrater. Berdasarkan hasil analisis buku teks yang dilakukan disimpulkan bahwa: (1) sistematika penyajian buku masih terdapat kekurangan dalam sistematika penyusunan, (2) keruntutan penyajian buku teks layak dan memiliki hubungan yang logis, (3) kelayakan penyajian isi buku teks memuat materi yang sesuai dengan kompetensi dan perkembangan intelektual peserta didik, dan (4) kelayakan bahasa buku teks sesuai dengan pedoman umum ejaan bahasa Indonesia.
\end{abstract}

Kata Kunci: analisis konten, buku teks, bahasa Indonesia

\section{A. PENDAHULUAN}

Pendidikan merupakan kebutuhan yang penting bagi setiap manusia. Dalam dunia pendidikan terdapat kegiatan belajar mengajar atau yang sering disebut dengan pembelajaran. Kegiatan pembelajaran tidak akan berjalan jika tidak didukung dengan adanya media pembelajaran. Salah satu media pembelajaran yang tidak lepas dari kegiatan belajar yaitu buku teks. Suatu buku teks harus mampu menunjang suatu program pengajaran pembelajaran.

Buku teks merupakan buku acuan yang wajib dipakai di sekolah yang memuat materi pembelajaran dalam ranah untuk meningkatkan sikap spiritual, pengetahuan serta kemampuan dari peserta didik (Pemendiknas No 2 Tahun 2008). Berdasarkan aturan Pemendiknas No 2 Tahun 2008 tersebut, mewajibkan sekolah untuk menggunakan buku teks, maka pemerintah ikut berperan dalam melaksanakan peraturan tersebut dengan mengadakan buku teks yang dikeluarkan oleh negara atau pemerintah berdasarkan kurikulum nasional, sedangkan untuk buku pendamping mata pelajaran tertentu diadakan oleh penerbit lokal berdasarkan standar nasional pendidikan, dan kelayakan buku teks yang sudah ditetapkan oleh Gubernur. 
Chambliss dan Calfee dalam Muslich (2010: 50) mengemukakan bahwa buku teks merupakan alat bantu peserta didik untuk dapat memahami dan belajar dari hal-hal yang dibaca dan untuk memahami dunia di luar dirinya. Buku dapat dipakai sebagai sarana belajar dalam 
kegiatan pembelajran di sekolah (Agustina, 2011: 10). Buku teks mempunyai peran penting yang sangat besar terhadap perubahan otak peserta didik. Oleh karena itu, buku teks dapat mempengaruhi pengetahuan anak dalam proses belajar mengajar. Di dalam kegiatan belajar peserta didik tidak hanya mencermati apa yang dijelaskan oleh guru. Peserta didik juga membutuhkan referensi untuk menggali ilmu agar pemahamannya lebih luas dan kemampuannya dapat lebih dioptimalkan. Dengan adanya buku teks, peserta didik dituntut untuk dapat berlatih, mempraktikan maupun mencoba teori-teori yang sudah dipelajari dalam buku teks tersebut. Peran guru harus cerdas dan cermah untuk menentukan buku ajar karya siapa yang akan digunakan di dalam proses kegiatan pembelajran. Jika seseorang guru dapat menentukan buku ajar yang baik, maka hal tersebut akan sangat berpengaruh besar di dalam proses kegiatan pembelajaran nantinya.

Buku teks merupakan buku yang berisi ilmu pengetahuan hasil analisis terhadap kurikulum yang dibentuk dalam wujud tertulis. buku teks disusun dengan menggunakan bahasa yang sederhana, menarik, dilengkapi dengan gambar, keterangan, isi buku, dan daftar pustaka. Buku teks sangat membantu guru maupun peserta didik dalam mendalami ilmu pengetahuan sesuai dengan mata pelajarannya. Buku teks yang berkualitas wajib memenuhi empat unsur kelayakan, yaitu kelayakan bahasa, kelayakan penyajian, kelayakan isi, serta kelayakan grafik dari buku tersebut. Buku teks Pintar Bahasa Indonesia kelas VII SMP/MTs semester 1 kurikulum 2013 terbitan Graha Printama Selaras merupakan salah satu buku pendamping Bahasa Indonesia yang telah dinilai kelayakannya oleh tim penilai buku teks dari BSNP (Badan Standar Nasional Pendidikan). Namun peneliti menemukan beberapa ketidaksesuaian yang terdapat pada buku teks Pintar Bahasa Indonesia kelas VII SMP/MTs kurikulum 2013. Setelah menemukan analisis awal, peneliti menemukan kesalahan pada aspek isi atau materi, bahasa, dan penyajian dalam buku teks tersebut.

Kualitas buku teks salah satunya dapat dilihat dari segi kelayakan bahasa. Kelayakan dari penggunaan bahasa dalam materi buku teks dapat ditinjau dari beberapa aspek. Materi dinilai lugas dan ditinjau dari tiga aspek yaitu dari keefektifan kalimat, ketepatan kata, kebakuan istilah. Hal yang harus diperhatikan dalam pembuatan bahan ajar mampu membuat peserta didik untuk belajar mandiri dan memperoleh ketuntasan dalam proses belajar karena peserta didik belajar secara mandiri sehingga bahasa yang digunakan cukup sederhana (Ika Lestari, 2013: 3). Buku teks haruslah sesuai dengan bahasa peserta didik, kalimat yang digunakan efektif, terhindar dari makna ganda, sederhana, serta sopan dan menarik. Kalimat yang dikatakan efektif apabila berhasil menyampaikan pesan, gagasan, informasi sesuai 
dengan maksud si pembicara atau penulis. Untuk itu, penyampaian harus memenuhi syarat sebagai kalimat yang baik dengan struktur yang benar, pilihan kata yang tepat, hubungan antar bagian yang logis, dan ejaan yang benar.

Penelitian ini berawal dari keraguan peneliti sendiri mengenai buku teks bahasa Indonesia yang digunakan pada sekolah sebagai buku pendamping yang digunakan dalam proses pembelajaran yang tidak diterbitkan oleh Kementerian Pendidikan dan Kebudayaan (Kemendikbud) Republik Indonesia, sehingga perlu adanya peninjauan ulang untuk melihat kelayakan dari buku teks. Dengan adanya penelitian ini diharapkan dapat memperbaiki kesalahan penulisan buku jika terdapat kekeliruan, dan dapat dilakukan proses perbaikan setelah ditemukannya kesalahan yang tidak sesuai dengan standar penerbitan buku serta kelayakan buku sesuai Permendikbud.

Berdasarkan uraian di atas, dapat dirumuskan permasalahan dalam penelitian ini, yaitu (1) bagaimana sistematika penyajian buku teks Pintar Bahasa Indonesia kelas VII semester I?; (2) bagaimana keruntutan penyajian buku teks Pintar Bahasa Indonesia kelas VII semester I?; (3) bagaimana kelayakan isi buku teks Pintar Bahasa Indonesia kelas VII semester I?; (4) bagaimana kelayakan penyajian bahasa dalam buku teks Pintar Bahasa Indonesia kelas VII semester I?.

Terdapat beberapa penelitian yang telah dilakukan terkait dengan kelayakan buku teks yang digunakan dalam proses kegiatan belajar mengajar dengan aspek tinjauan yang berbedabeda. Penelitian buku teks yang dilakukan oleh Hendrawanto dan Mulyani (2017) dengan judul “Kelayakan Kebahasaan dan Isi Buku Teks Bahasa Indonesia Kelas XII Semester I SMA” yang ditinjau secara lebih rinci pada unsur kebahasaan dan isi buku teks bahasa Indonesia. Hasil dari penelitian tersebut menunjukkan kelayakan aspek kebahasaan yang mendapatkan skor penilaian sebesar 50,97 dan penilaian terhadap isi buku teks dengan perolehan skor 52,27 sehingga dapat disimpulkan bahwa buku teks tersebut belum layak digunakan dalam proses pembelajaran bahasa Indonesia.

Penilitian lain yang berkaitan dengan buku teks Bahasa Indonesia dengan judul "Kelayakan Isi dan Bahasa Buku Ajar Bahasa Indonesia Sekolah Menengah Pertama kelas VII Kurikulum 2013 Edisi Revisi 2017 Penerbit Kementerian Pendidikan dan Kebudayaan” yang di tulis oleh Ridho dan Lubis (2018) yang ditinjau secara lebih rinci pada unsur kebahasaan buku dan isi dari buku teks bahasa Indonesia. Dari segi kelayakan isi sudah dikategorikan pada kategori yang layak dengan persentase $84,54 \%$ dan segi kelayakan bahasa juga sudah 
dikategorikan pada kategori yang layak dengan persentase $88,38 \%$. Hasil penelitian tersebut menunjukkan bahwa buku ajar bahasa Indonesia SMP kelas VIII edisi revisi 2017 Kemendikbud layak untuk digunakan untuk proses belajar mengajar di kelas.

Kelayakan buku teks bahasa Indonesia sangat diperlukan untuk dilakukan pada sebuah penelitian. Menganalisis buku teks merupakan cara untuk mendapatkan kualitas dari buku teks yang digunakan dalam pembelajaran. Agar buku teks yang digunakan memiliki kualitas yang baik dan sesuai dengan tujuan pembelajaran maka buku ajar harus memenuhi standar yang sudah ditentukan untuk dapat dikatakan buku tersebut layak untuk digunakan.

\section{B. KAJIAN PUSTAKA}

\section{Buku Teks}

Buku teks merupakan buku panduan yang digunakan oleh peserta didik maupun guru dalam kegiatan belajar mengajar. Buku teks yang digunakan merupakan buku yang menggunakan bahasa yang mudah dipahami, mengaitkan pengalaman sehari-hari dari peserta didik sehingga mudah untuk dimengerti oleh peserta didik. Husnita dan Zulva mengemukakan bahwa buku teks merupakan buku pegangan yang digunakan oleh guru dalam mengajar, selain itu buku teks juga digunakan peserta didik sebagai penunjang kegiatan pembelajaran baik di sekolah maupun di luar sekolah.

Menurut Tarigan (2009) buku teks merupakan buku pelajaran dalam bidang tertentu, yang merupakan buku standar dan disusun oleh para pakar. Hal ini mempunyai tujuan instruksional yang dilengkapi dengan sarana pengajaran yang serasi dan mudah dipahami oleh penggunanya di sekolah-sekolah maupun perguruan tinggi, sehingga dapat menunjang suatu program pengajaran.

Dapat disimpulkan bahwa buku teks adalah buku panduan yang digunakan baik untuk peserta didik maupun guru dalam proses belajar mengajar. Dengan adanya buku teks dapat mempermudah pengajaran yang melibatkan semua peserta didik di dalam kelas. Peserta didik juga akan lebih mudah dalam memahami dan menangkap materi yang dijelaskan karena materi yang disampaikan tertera dengan jelas di dalam buku teks.

\section{Penilaian Kelayakan Isi Buku Teks}

Muslich (2010) mengemukakan bahwa kelayakan isi buku teks ada tiga indikator yang harus diperhatikan, yaitu kesesuaian dengan uraian materi dalam Standar Kompetensi dan 
Kompetensi Dasar yang terdapat dalam mata pelajaran, keakuratan materi dan materi pendukung pembelajaran. Dari ketiga indikator tersebut kita dapat menilai sejauh mana tingkat dari kelayakan isi materi dalam sebuah buku teks, sehingga dapat mengetahui kekurangan serta kelebihan dari buku teks yang akan digunakan sebagai acuan dalam kegiatan belajar mengajar.

\section{METODE PENELITIAN}

Penelitian ini menggunakan metode analisis konten dengan pendekatan kualitatif. Penelitian analisis konten merupakan penelitian untuk membuat simpulan yang dapat direplikasi dari teks maupun materi yang penting lainnya dalam konteks penggunaannya (Krippendorff, 2004: 18). Analisis konten yang dimaksud merupakan analisis dokumen buku teks Bahasa Indonesia yang berjudul Pintar Bahasa Indonesia SMP/MTs Kelas VII Semester 1. Adapun bagian yang dianalisis merupakan aspek isi atau materi, bahasa dan penyajian buku teks pendamping.

Data dalam penelitian ini diperoleh menggunakan sampling dengan teknik nonrandom sampling dan purposive sampling. Sumber data sampling adalah buku teks Bahasa Indonesia yang berjudul Pintar Bahasa Indonesia SMP/MTs Kelas VII Semester 1. Buku ini dijadikan sampling dalam penelitian karena telah dijadikan sebagai buku wajib bagi peserta didik maupun guru. Unit analisis dalam penelitian ini merupakan aspek isi atau materi, bahasa dan penyajian yang termuat di dalam buku teks tersebut. Pengumpulan data dengan cara analisis secara cermat dan pencatatan tentang aspek isi atau materi, bahasa, dan penyajian yang terdapat di dalam buku teks. Adapun instrumennya merupakan peneliti sendiri.

Keabsahan data dalam penilitian ini berdasarkan validitas dan reliabilitas. Validitas data menggunakan validitas semantik yaitu dengan cara mengamati data-data pada bagian pendahuluan yang terdiri dari kalimat motivasi dan ilustrasi gambar serta tujuan dan ruang lingkup pembelajaran. Bagian inti terdiri atas uraian dari materi pelajaran, tugas individu, dan tugas kelompok, sedangkan pada bagian penutup terdiri atas refleksi, uji kompetensi, dan penilaian afektif. Reliabilitas yang digunakan dalam penelitian ini merupakan reliabilitas intrariter, yaitu menggunakan cara membaca dan mengkaji ulang untuk mendapatkan data yang konsisten.

\section{HASIL DAN PEMBAHASAN}

Hasil yang disajikan adalah bentuk kelayakan penyajian bahasa, dan isi buku teks Pintar Bahasa Indonesia SMP/MTs Kelas VII semester I. Berdasarkan analisis data yang 
dilakukan, peneliti menemukan beberapa data bentuk dari kelayakan penyajian buku teks tersebut. Data tersebut kemudian oleh peneliti dijabarkan sesuai dengan tujuan penelitian.

Tabel 1. Sistematika Penyajian Buku Teks Pintar Bahasa Indonesia SMP/Mts Kelas VII Semester 1

\begin{tabular}{lccc}
\hline & Pembangkit Motivasi & Kelengkapan Materi & $\begin{array}{l}\text { Sesuai } \\
\text { dengan } \\
\text { Kwrikulum }\end{array}$ \\
\hline Bab I & $\sqrt{ }$ & $\sqrt{ }$ & $\sqrt{ }$ \\
Bab II & $\sqrt{ }$ & $\sqrt{ }$ & $\sqrt{ }$ \\
Bab III & $\sqrt{ }$ & $\sqrt{ }$ & $\sqrt{ }$ \\
\hline Bab IV & - & $\sqrt{ }$ & \multicolumn{2}{c}{} \\
\hline
\end{tabular}

\section{Sistematika Penyajian}

\section{Data 1}

\section{Bab 1 (Belajar Mendeskripsikan)}

Dalam bab 1 memuat kegiatan mandiri dan kegiatan kelompok. Pembangkit motivasi yang disajikan dalam bab 1 berupa gambar, yaitu gambar 1.1 ruang tamu sederhana, 1.2 pantai tiga warna di Malang, 1.3 ilustrasi seorang gadis, dan 1.4 air terjun Lembah Pelangi di Tenggamus Lampung. Pendahuluan yang disajikan berupa materi singkat untuk peserta didik dengan pokok pembahasan teks deskripsi. Materi yang dibahas mengenai struktur teks deskripsi, menelaah isi teks deskripsi, menelaah penggunaan bahasa dalam teks deskripsi, menyajikan teks deskripsi secara lisan dan tertulis, dan menyunting teks deskripsi. Isi dari materi yang disajikan di dalam buku teks tersebut sesuai dengan kurikulum yang berlaku dan mampu untuk mendukung kegiatan belajar bagi peserta didik.

\section{Data 2}

\section{Bab 2 (Memahami dan Menciptakan Cerita Fantasi)}

Bab 2 memuat beberapa kegiatan mandiri, kegiatan kelompok, dan latihan kompetensi. Pembangkit motivasi yang disajikan di dalam bab 2 ini berupa gambar, yaitu gambar 2.1 timun mas. Pendahuluan yang disajikan berupa materi singkat tentang teks cerita fantasi. Materi yang dibahas di dalam buku teks tersebut mengenai identifikasi unsur teks cerita fantasi, menceritakan kembali isi cerita fantasi yang dibaca maupun didengar, menelaah struktur dan 
bahasa dari cerita fantasi, dan menyajikan cerita fantasi. Isi materi yang disajikan di dalam buku teks sesuai dengan kurikulum yang berlaku.

\section{Data 3}

\section{Bab 3 (Mewariskan Budaya Melalui Teks Prosedur)}

Dalam bab 3 memuat kegiatan mandiri, kegiatan kelompok, dan latihan kompetensi. Pembangkit motivasi yang disajikan di dalam buku teks berupa gambar, yaitu gambar 3.1 sasando. Pendahuluan yang disajikan berupa materi singkat mengenai teks prosuder. Materi yang dibahas mengenai identifikasi ciri teks prosedur, menyimpulkan isi teks prosedur, menelaah struktur dan bahasa pada teks prosedur, serta menulis dan memeragakan teks prosedur. Materi yang disajikan mampu mempermudah dari proses kegiatan belajar peserta didik.

\section{Data 4}

\section{Bab 4 (Menyibak Ilmu dalam Laporan Hasil Observasi)}

Bab 4 memuat kegiatan mandiri, kegiatan kelompok, dan latihan kompentensi. Pada bab 4 buku teks Pintar Bahasa Indonesia ini tidak mempunyai pembangkit motivasi yang disajikan di dalam buku teks tersebut. Pendahuluan yang disajikan berupa materi singkat untuk peserta didik dengan pokok bahasan teks laporan hasil observasi. Materi yang dibahas mengenai identifikasi teks hasil observasi, menyimpulkan isi teks laporan hasil observasi yang berupa buku pengetahuan yang dibaca maupun didengar, menelaah struktur dan bahasa dari teks laporan hasil observasi, serta merangkum dan menyajikan laporan hasil observasi. Isi materi yang disajikan di dalam buku teks tersebut sesuai dengan kurikulum yang berlaku dan mampu untuk mendukung kegiatan belajar peserta didik.

\section{Kelayakan Penyajian Buku}

Unsur kulit buku teks terdiri atas bagian kulit depan, punggung buku, dan kulit belakang. Kulit depan buku teks memiliki warna putih dan gambar siswa berdiskusi di perpustakaan. Pada bagian kulit depan terdapat judul di sisi kiri buku dengan unsur warna biru, hijau, dan hitam disertai dengan jenjang dan semester dibagian judul. Tulisan Pintar sebagai nama buku terletak di sisi kiri atas buku dengan unsur warna biru dan latar belakang warna putih. Pada sudut kanan bagian bawah buku terdapat tulisan "VII" sebagai penunjuk buku yang diperuntukkan bagi siswa kelas tujuh dengan warna hitam dan latar belakang warna putih, 
sedangakan pada bagian kiri atas buku terdapat tulisan "Dilengkapi soal-soal HOTS" tulisan ini memberikan informasi bahwa soal-soal di dalam buku berorientasi pada HOTS (Higher Order Thinking Skill), tulisan tersebut berwarna merah dengan latar belakang warna putih, serta pada bagian sudut ujung kiri buku terdapat tulisan "berdasarkan Permendikbud No. 37 tahun 2018 Penyempurnaan Permendikbud No. 24/2016". Pada bagian atas tengah buku terdapat nama penulis dari buku teks Pintar Bahasa Indonesia dengan warna hitam dan latar belakang putih.

Berdasarkan buku pedoman penerbitan yang ditulis oleh Tim E-Learning Publishing LIPI (2017: 35), unsur-unsur yang dicantumkan pada sampul depan buku, termasuk: judul utama, subjudul (jika ada), nama penulis, dan logo dari penerbit. Pencantuman nama penulis tanpa disertai dengan gelar akademik, pangkat atau jabatan. Penulisan logo penerbit juga tanpa disertai dengan status badan hukum penerbit seperti PT, CV, Yayasan atau sejenisnya. Logo dari penerbit diletakkan pada bagian sudut atas sisi kiri sampul depan dan punggung buku.

Bagian punggung buku yang terdapat dalam buku teks Pintar Bahasa Indonesia untuk SMP/MTs Kelas VII semester I mememiliki unsur tulisan yang tak jauh beda dengan sampul buku, hanya saja memiliki beberapa perbedaan, antara lain: pada bagian punggung buku tidak terdapat tulisan "dilengkapi soal-soal HOTS", "berdasarkan Permendikbud No. 37 tahun 2018 Penyempurnaan Permendikbud No. 24/2016" dan warna yang digunakan pada bagian punggung buku ini menggunakan perpaduan warna putih dan ungu.

Sesuai dengan buku pedoman yang diterbitkan dan disusun oleh Tim E-Learning Publishing LIPI (2017: 36), teks pada punggung buku dituliskan jika buku mencapai 0,15 mm atau mempunyai 112 halaman. Unsur-unsur yang dicantumkan pada punggung buku, antara lain: logo, judul buku, subjudul (jika ada), dan nama penulis.

Pada unsur kulit belakang buku teks memiliki perpaduan antara warna putih dan ungu. Terdapat tulisan menganai "meraih prestasi melalui kegiatan tulis-menulis" dan keterangan lengkap perusahaan yang menerbitkan buku teks tersebut. Berdasarkan pedoman penulisan buku oleh Tim E-Learning Publishing LIPI (2017: 36) unsur-unsur yang harus dicantumkan dalam kulit belakang buku antara lain: biografi pengarang, judul buku diletakkan di bagian atas dan ukurannya lebih kecil dari judul pada kulit depan, nama dan alamat distributor serta testimoni (jika ada). 


\section{Kelayakan Isi pada Buku Teks Pintar Bahasa Indonesia Kelas VII SMP/MTs}

\section{a. Kelengkapan materi}

Kelengkapan materi pada buku ini masuk pada kategori layak. Hal ini dinilai dari beberapa bab yang sudah memuat KI beserta KD pada setiap bab. Hanya saja beberapa wacana, contoh dan latihan pada bab tersebut tidak memuat penjabaran KD.

\section{b. Kedalaman Materi}

Kedalaman materi pada buku ini termasuk kategori yang layak. Hal tersebut dinilai dari beberapa bab yang sudah membahas konsep, definisi, prosedur, contoh, dan pelatihan secara rinci yang dapat diterapkan sesuai dengan KI dan KD.

\section{c. Pemilihan Wacana, Teks, Gambar, dan Ilustrasi sesuai dengan Kompetensi yang harus dicapai dan bermanfaat bagi pemenuhan rasa ingin tahu}

Pemilihan wacana, teks, gambar dan ilustrasi ini masuk dalam kategori cukup. Hal ini dilihat dari unsur pembangkit motivasi adanya gambar dan ilustrasi yang sangat sedikit dan kualitas gambar yang kurang membuat buku teks tersebut monoton, sehingga rasa ingin tahu peserta didik dalam memahami wacana maupun teks masih kurang.

\section{d. Konsep dan teori}

Konsep dan teori sesuai dengan definisi yang belaku dalam bidang ilmu dibahasa secara akurat dan rinci. Dari keempat bab yang ada di dalam buku ini sudah sangat akurat dalam menyajikan konsep dan teori yang sesuai dan tidak menimbulkan makna ganda yang membuat peserta didik menjadi bingung untuk memahami. Hal ini membuat peserta didik lebih mudah untuk memahami isi buku teks tersebut.

\section{e. Pelatihan, penugasan dan penilaian}

Pelatihan, penugasan serta penilaian sesuai dengan tuntutan dari penilaian autentik. Semua bab di dalam buku teks ini sudah masuk dalam kategori baik dan akurat dalam menyajikan konsep dan teori yang sesuai dengan pelatihan tugas dan soal-soal yang diajukan dapat mengukur kemampuan pengetahuan, sikap, dan keterampilan dari peserta didik sesuai dengan pedoman penilaian autentik dan tidak ada soal yang dapat menimbulkan adanya makna ganda yang akan membuat siswa menjadi bingung. Hal ini akan memudahkan peserta didik dalam mengembangan dirinya. 


\section{f. Pengembangan Wawasan Kebangsaan}

Dalam buku ini sangat kurang dalam menyajikan pengembangan wawasan kebhinekaan maupun kebangsaan dalam wacana, contoh, dan latihan soal. Semua bab pada buku ini disajikan tanpa dapat mengembangan wawasan kebangsaan dan integrasi bangsa yang dapat mengajak peserta didik untuk mencintai bahasa Indonesia.

\section{g. Tidak mengandung unsur SARA, Pornografi dan Bias (Gender, Wilayah, dsb)}

Dalam buku ini tidak ditemukan materi yang disajikan melalui wacana, teks, gambar, dan ilustrasi yang mengandung unsur SARA, pornografi, dan bias. Buku ini menyajikan materi yang sangat teliti dan rinci tanpa memual hal-hal yang sensitif dan negatif. Hal ini sangat baik dalam membangun moral seorang peserta didik dalam membaca buku tersebut.

\section{Kelayakan bahasa}

\section{a. Kesesuaian dengan tingkat intelektual}

Kesesuaian bahasa dengan tingkat perkembangan intelektual peserta didik pada buku ini masuk dalam kategori layak. Dalam buku ini pemilihan bahasa dalam wacana, contoh serta latihan soal mampu diabstraksi secara logis dan rasional oleh peserta didik dan setiap pelatihan yang bersifat hipotesis mampu diselesaikan.

\section{b. Kesesuaian dengan tingkat perkembangan sosial emosional}

Kesesuaian dengan tingkat perkembangan sosial emosional peserta didik diperoleh dalam buku ini menggunakan bahasa yang sesuai dengan tingkat perkembangan sosial dan emosional peserta didik pada wacana, contoh, dan latihan soal yang telah disajikan. Kesesuaian bahasa dengan tingkat perkembangan sosial dan emosional peserta didik dapat dilihat dari wacana, teks, dan gambar yang menggambarkan konsep-konsep mulai dari lingkungan dan kebudayaan,

\section{c. Ketepatan bahasa}

Ketepatan bahasa dalam buku ini dinilai dengan penggunaan bahasa yang sangat baik karena sesuai dengan pedoman umum ejaan bahasa Indonesia. Tetapi, ada beberapa kalimat yang tergolong cukup baik karena masih ada penggunaan bahasa yang kurang baku dan belum sesuai dengan pedoman umum ejaan bahasa Indonesia. 


\section{Keruntutan dan Keterpaduan Penyajian Buku}

Keruntutan dan keterpaduan penyajian buku ini dalam kategori yang sangat sesuai. Buku ini sudah sangat baik dalam penyampaian pesan antara satu bab dengan bab yang berdekatan dan antar subbab dalam bab mencerminkan hubungan yang logis. Kemudian, buku teks Pintar Bahasa Indonesia ini juga sudah sangat baik dalam penyampaian pesan antara satu paragraf dan paragraf lain yang berdekatan dan antarkalimat dalam paragraf mencerminkan hubungan yang logis. Keruntutan penyajian dalam buku teks Pintar Bahasa Indonesia menerapkan alur deduktif. Pada bab 1 materi yang disajikan sudah runtut, yaitu materi teks deskripsi, menentukan ciri, isi, dan tujuan teks deskripsi, struktur dan bahasa teks deskripsi, menyunting dan menyajikan teks deskripsi. Materi tersebut sudah runtut mulai dari yang umum ke khusus. Begitu juga dengan bab selanjutnya materi yang disampaikan juga menerapkan alur deduktif di mana materi yang disajikan secara runtut mulai dari yang umum hingga khusus. Jadi, peserta didik lebih mudah dan dapat memahami materi yang ada di dalam buku teks tersebut.

\section{E. KESIMPULAN}

Buku teks pendamping yang berjudul Pintar Bahasa Indonesia SMP kelas VII semester I penerbit Graha Printama Selaras dari segi kelayakan isi buku sudah dikategorikan pada kategori yang layak. Isi dalam buku tersebut sudah memuat materi yang sesuai dengan kompetensi yang harus dicapai oleh peserta didik. Kedalaman materi pada buku teks tersebut juga sudah baik dan lengkap yang telah disajikan pada wacana, teks, dan latihan soal. Keakuratan materi pada buku teks ini sudah akurat, hanya saja pendukung materi pembelajaran pada buku teks tersebut kurang menyajikan wacana, contoh teks, dan latihan soal yang dapat mengembangkan wawasan kebangsaan, kebhinekaan serta integritas bangsa yang mampu mengajak peserta didik untuk mencintai bahasa Indonesia. Keruntutan dan keterpaduan dalam penyajian buku teks ini juga layak dan memiliki hubungan yang logis antara satu bab dengan bab yang lainnya dan paragraf satu dengan paragraf lain.

\section{F. SARAN}

Berdasarkan kesimpulan di atas, peneliti memiliki beberapa saran sebagai berikut. Pertama, peserta didik hendaknya memilih buku yang berkualitas sebagai buku acuan dan menggunakan referensi lain untuk mendukung kegiatan pembelajaran. Kedua, guru juga sebaiknya perlu memilih buku ajar yang memiliki kualitas baik dan dapat direkomendasikan kepada peserta didik sebagai media pembelajaran, sehingga dapat menghindari adanya 
kesalahpahaman materi yang digunakan dalam kegiatan pembelajaran. Ketiga, penerbit maupun penulis buku teks sebaiknya merevisi kelengkapan materi pada buku teks.

\section{DAFTAR PUSTAKA}

Agustina, Eka Sofia. 2011. Materi Ajar BTBI. Lampung: Universitas Lampung.

Badan Standar Nasional Indonesia. Instrumen Penilaian Buku Ajar. (http://bsnp-indonesia.org/2014/05/28/instrumen-penilaian-buku-teks-pelajarantahun-2014/) diakses 20 Desember 2019.

Krippendorff, Klaus. 2004. Content analysis an introduction to its methodology. London: International Education and Professional Publisher.

Lestari, Ika. 2013. Pengembangan Bahan Ajar Berbasis Kompetensi. Padang: Akademia Husnita, Liza dan Zulfa. 2015. Analisis kelengkapan materi buku teks sejarah kelas XI yang dipakai di sekolah-sekolah SMA di Kota Padang (Buku Erlangga, Platinum, Bumi Aksara dan Yudistira). Jurnal Pelangi, 7 (2), hlm 148- 165.

Muslich, Masnur. 2010. Text Book Writing. Jakarta: Ar-ruzz Media.

Peraturan Menteri Pendidikan Nasional Nomor 2 Tahun 2008 tentang Buku.

Permendikbud. 2018. Peraturan Menteri Pendidikan dan Kebudayaan No. 37 tahun 2018 tentang Kompetensi Inti dan Kompetensi Dasar Pelajaran pada Kurikulum 2013 pada Pendidikan Dasar dan Pendidikan Menengah.

Pradita, Ridho M., \& Fitriani Lubis. 2018. Kelayakan Isi dan Bahasa Buku Ajar Bahasa Indonesia Sekolah Menengah Pertama Kelas VIII Kurikulum 2013 Edisi Revisi 2017 Penerbit Kementerian Pendidikan dan Kebudayaan. Basastra: Jurnal Kajian Bahasa dan Sastra Indonesia, Vol 7, No 4, hal 281- 294.

Tarigan, H, G \& Tarigan, D. 2009. Telaah Buku Teks Bahasa Indonesia. Bandung: Angkasa Tim E-learning Publishing. 2017. Pedoman Penerbitan Buku LIPI Press: Jakarta: Lipi Press. Yusuf, H., \& Mimi, M. 2017. Kelayakan Kebahasaan dan Isi Buku Teks Bahasa Indonesia Kelas XII Semester I SMA. JP-BSI: Jurnal Pendidikan Bahasa dan Sastra Indonesia, Vol 2, No 2, Hal 58-62. 